\title{
Ethnobotanical Study of Wild Edible Plants and Their Indigenous Knowledge in Sedie Muja District, South Gondar Zone, Northwestern Ethiopia
}

\author{
Merkuz Abera, Kindye Belay \\ Department of Plant Sciences, College of Agriculture and Environmental Sciences, Bahir Dar University, Bahir Dar, Ethiopia \\ Email: merkuzabera@yahoo.com
}

How to cite this paper: Abera, M. and Belay, K. (2022) Ethnobotanical Study of Wild Edible Plants and Their Indigenous Knowledge in Sedie Muja District, South Gondar Zone, Northwestern Ethiopia. American Journal of Plant Sciences, 13, 241-264. https://doi.org/10.4236/ajps.2022.132015

Received: January 9, 2022

Accepted: February 19, 2022

Published: February 22, 2022

Copyright ( 2022 by author(s) and Scientific Research Publishing Inc. This work is licensed under the Creative Commons Attribution International License (CC BY 4.0).

http://creativecommons.org/licenses/by/4.0/

\section{(c) (i) Open Access}

\begin{abstract}
Wild edible plants have played a vital role in supplementing the diet of people in developing countries. People in Sedie Muja District, South Gondar Zone, consume different parts of wild plants. This study was done in Sedie Muja District, South Gondar Zone to deal with ethnobotanical uses of selected wild edible plants. Field surveys were carried out in 2018-2019. Ethnobotanical data were collected from 84 respondents using semi-structured interview, guided field walk, market survey and field observations. Preference ranking, direct matrix ranking and informant consensus with buyers, sellers, cookers and elderly people of the user groups were used for data analysis. A total of 33 wild edible plants were documented. Of these families, Moraceae, Fabaceae and Solanaceae were the most dominant families that account 3 (11.5\%) species each. Fruits are the most edible parts compared to the other edible plant parts that account 18 (54.5\%). These species can be promoted for large-scale cultivation and marketing for the benefit of the local communities.
\end{abstract}

\section{Keywords}

Ethnobotanical, Indigenous Knowledge, Wild Edible

\section{Introduction}

Different parts of uncultivated plant species (wild edible plants) are consumed by people. The major edible parts include fruits, leaves, seed, root and tuber are consumed as food [1]. Wild edible plants (WEPs) have played a vital role in supplementing the diet of people in developing countries. Due to the speedy 
growth of population, scarcity of fertile land for cultivation and high prices of available staples, the poor people frequently collect wild edible plants [2] and this is done especially during periods of food shortage [3]. Utilization of wild edible plants as a food source is an integral part of the culture of indigenous people that dwell in the rain forests of Africa and South America who gather and consume wild edible plants as snacks and at times of food scarcity [4].

The study on the use of wild edible plants in different parts of Africa indicated that they are integral in the diet of the people. In Mozambique, a survey of wild plants used by native people was reported by Santos and Fidalgo in 1975. They studied edible leaves, which are used all over the country. The studied plants included Amaranthus caudatus, A. gracilis, A. graecizans, A. spinosus, Corchorus trilocularis, C. tridens, Colocasia antiquorum and Bidens pilosa [5].

Ethiopia's topography, climate, biological and social diversity have led to varied traditional knowledge and wild edible plant species that are indispensable for food, nutrition security and have a greater potential for income generation and ecosystem services [6]. In the southern part of Ethiopia, wild edible plants are used as supplements to cultivated crops and as a survival strategy during food shortages that appear to have been intensified due to the low development of agriculture and the repeated lack of rain. Food insecurity remains a persistent problem in Ethiopia. Drought, floods and the attention of local knowledge leads to food insecurity situations where high quality food plant species are underutilized and mismanaged [7]. Similarly, consumption of WEPs is common in Northern Ethiopia. Plants that are edible in this part of the country include Adansonia digitata, Balanites aegyptiaca, Carissa spinarum, Cordia africana, Tamarindus indica, Ximenia americana and Ziziphus spina-christi. However, there is an increase of acculturation, displacement of indigenous communities, diminishing biodiversity, due to population pressure and climate change that led to a decline in the use of wild edible plants and associated knowledge. These factors led to the decline in knowledge about wild food plants, especially among young people. The food value and cultural importance, in Ethiopia, are under estimated and lack adequate attention [8].

In most parts of Ethiopia, wild edible plants are integral parts of the feeding habits of many communities [9]. However, consumption of wild edible plants is more common in food-insecure areas than in other areas in the country. According to [3], despite the wide availability and utilization of WEPs in Ethiopia, ethnobotanical information on cultural and socio-economic value of Ethiopian wild edible plants is limited. Sedie Muja district is one of the food insecure areas from the south Gondar zone. Due to this and since there is no documented work on the ethnobotany of WEPs in the area there is still a need for documentation and domestication of WEPs to assist in the nationwide effort to combat food insecurity and ensure dietetic diversity.

Therefore this study was initiated to assess and list wild edible plant species used as food by the community and to compile the available indigenous know- 
ledge used by people in Sedie Muja District.

\section{Materials and Methods}

\subsection{Description of the Study Area}

The study was conducted at Sedie Muja District, South Gondar Zone, Amhara Regional State North-Western Ethiopia (Figure 1). Sedie Muja District is located at a distance of $772 \mathrm{~km}$ from Addis Ababa (capital city). It is $209 \mathrm{~km}$ from Bahir Dar city (regional city) and $105 \mathrm{~km}$ from Debre Tabor (zone town). This district is located between, $11^{\circ} 29^{\prime} 59.99^{\prime \prime}-11^{\circ} 15^{\prime} 36^{\prime \prime}$ and $38^{\circ} 14^{\prime} 60^{\prime \prime}-38^{\circ} 37^{\prime} 42^{\prime \prime}$ latitude and longitude respectively. The elevation ranges from $1700-2500 \mathrm{~m}$ above sea level and the mean annual minimum and maximum temperature are $14^{\circ} \mathrm{C}-28^{\circ} \mathrm{C}$ and rainfall $200-900 \mathrm{~mm}$ [10]. The district has three climatic zones, namely, Dega (above $2500 \mathrm{~m}$ ), Woina dega $(2500-1800 \mathrm{~m}$ ) and Kola (below 1800) and the topography of the district consists of high land, mid-high land and low land based on altitudinal classification [10].

The district has a total of 21 Kebele Administrations (KAs) and the total population of the district is 227, 271, out of which 112822 are males and 114449 are females. The livelihood of this population is based on mixed farming. The study area is one of the foods unsecured and drought prone districts in the region. The district is bordered to the South by South Wollo District, to West by Misraq Estie District and to the North by Tach Gaynt District respectively. Land resources can be used for different socio-economic purposes. As the data obtained from Office of Agriculture and personal field observation indicate that the land use patterns of the study district are characterized by a mixture of categories as: cultivated, forests, bushes, shrubs, grazing lands, water body, and residential areas [10].

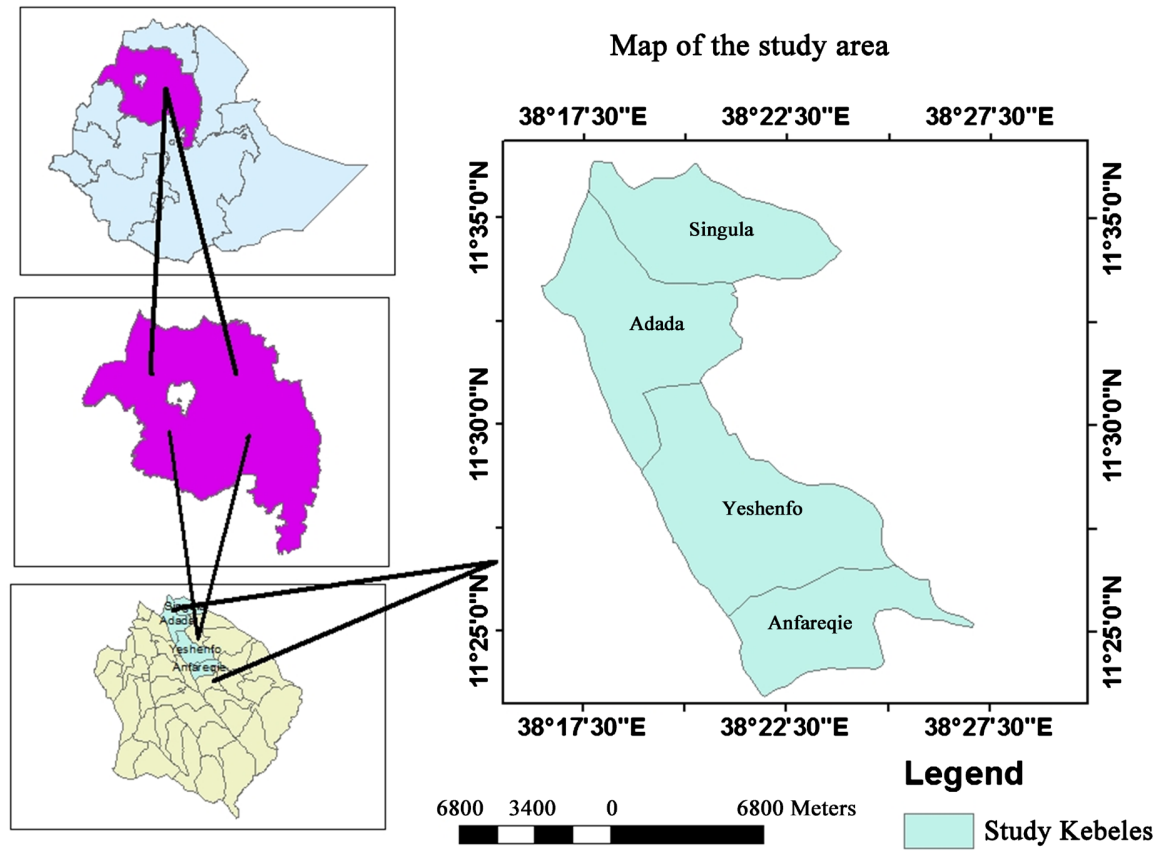

Figure 1. Map of the Study Area (Developed by Arc Map 10.3). 
Rainfall is erratic and steadily declined over the years, leading to extended drought periods and change in crop types grown. High population pressure is responsible for expansion of the agricultural area. The most widely occurring soil types in the area are red soil, brown soil and black soil. The people discriminately know crop plants that can grow in each soil types [10].

\subsection{Study Design}

Field-based cross-sectional study was employed. Reconnaissance survey was conducted at first to have a mental picture of the study area in order to obtain an impression of wild edible plants and a general understanding of the characteristics of the study areas.

\subsection{Method of Data Collection}

\subsubsection{Ethnobotanical Data Collection}

\section{1) Site Selection}

Four Kebele Administrations, namely Singula, Adada, Yeshenfo and Anfaregie, were selected from 21 Kebele Administrations purposively based on availability of wild edible plants as advised by local administers and elders.

\section{2) Informant Selection}

Permission from the official and community members was obtained before conducting this research. The goal, methodology and outcome of this research was clearly and honestly discussed with local communities. Selection of informants was performed following [11]. A total of 84 informants (66 general and 18 key informants) were selected from the 4 Kebele Administrations (Table 1). For the general informant's 14 - 18 individuals from each of the $4 \mathrm{KAs}$ were selected randomly by lottery method from a given list of inhabitants of each $K$ A to collect data about perception, use, management and conservation of wild edible plants and the overall human and wild edible plants interaction. From each of the 4 study KAs 4 - 6 key informants were purposively selected with the help of administers and elders. The key informants include elders, wild edible plant collectors, sellers, cookers and buyers of the species.

\section{3) Semi-Structured Interview}

Ethnobotanical data were collected through semi-structured interview with all informants and knowledgeable elders using pre-prepared interview. Required historical and cultural data were collected. All interviews were held based on check list of questions prepared beforehand in English language and translated into Amharic, the language of inhabitants. Interviewees were visited at their working places or their homes.

Key informants were expected to have a particular insight or opinion about the subject under investigation. Plant consumption, way of collection, preparation, parts used and marketability of species were collected [11]. In addition, semi-structured interviews were asked about existing threats and traditional conservation practices, taboos/beliefs related and way of indigenous knowledge transfer. The semi-structured interviews were taken using independent walks 
which allowed for more discussion with individual informants and the practical identification and collection of useful plants in their natural environment (Figure 2).

\section{4) Guided Field Walks}

It is an interview done while walking through the areas where the plants of interest were found (Figure 3). Voucher specimen collection and recordings were done at spot while the interview is undergoing. This method gives opportunity for the researcher to make note on the habitat, habit, appearance and relation with

Table 1. Socio-demography of informants in Sedie Muja District.

\begin{tabular}{lcc}
\hline & Number & Percentage \\
\hline Gender & 50 & 59.5 \\
Male & 34 & 40.5 \\
Female & 84 & 100 \\
Total & & \\
Educational status & 54 & 64.2 \\
Illiterate (unable to read and write) & 30 & 35.8 \\
Literate (able to read and write) & 84 & 100 \\
Total & & \\
Marital status of informant & 51 & 60.7 \\
Married & 33 & 39.3 \\
Single & 84 & 100 \\
Total & & 58.4 \\
Age of informants & 35 & 100 \\
15 - 35 & & 41.6 \\
$>35$ & & \\
Total & 39 & \\
\hline
\end{tabular}

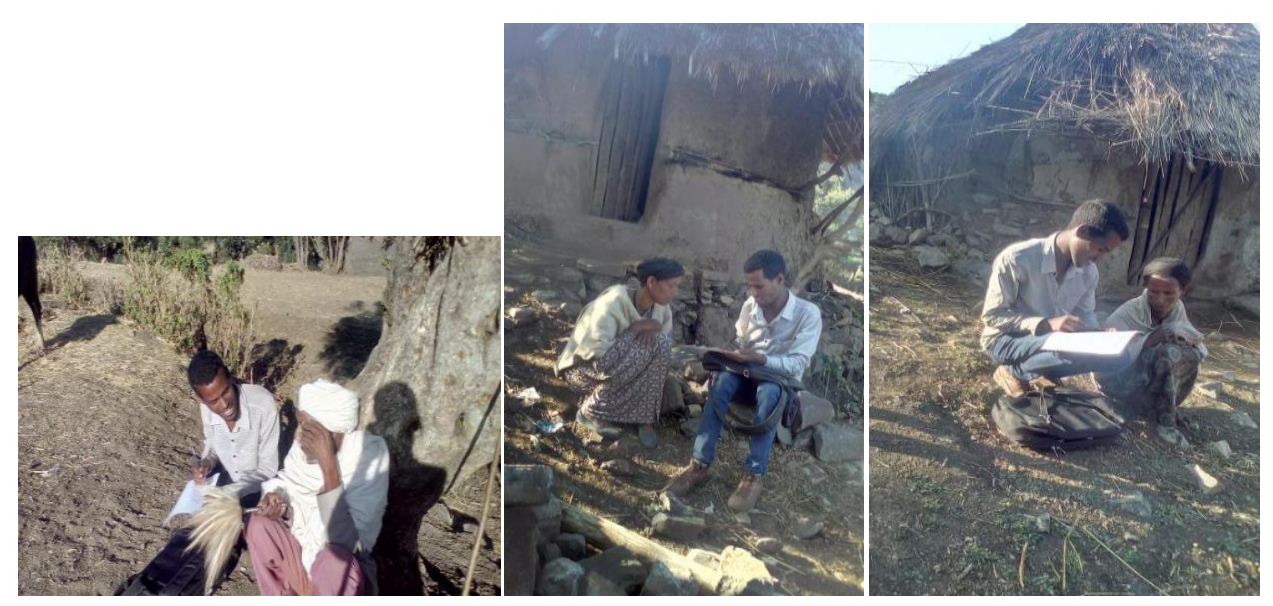

Figure 2. Semi-structured interview with informants. 
other species using all the senses but the method is very tiresome and time consuming.

\section{5) Focus Group Discussions (FGD)}

Focus group discussions (composed informants from each of four Kebele Administrations) were administered by selecting individuals from different areas including, elders, men, women and youngsters to have triangulated data on WEPs while they have reached at consensus. The information collected by group discussion was helpful to compare information collected through semi-structured interviews. Brief focus group discussions were made prior and during ethnobotanical data collection. These were done with WEP sellers, buyers, collectors and other knowledgeable members on specified time in each site. At the end of interview the contribution of each informant was appreciated, indicating the value of their knowledge on WEPs use and conservation. Participants were requested to list down the most preferred and used plant species by the community at any situation in the Kebele Administrations to select widely used WEPs (Figure 4).

\section{6) Market Survey}

Many towns have sections where wild edible plants, fruits and other plant
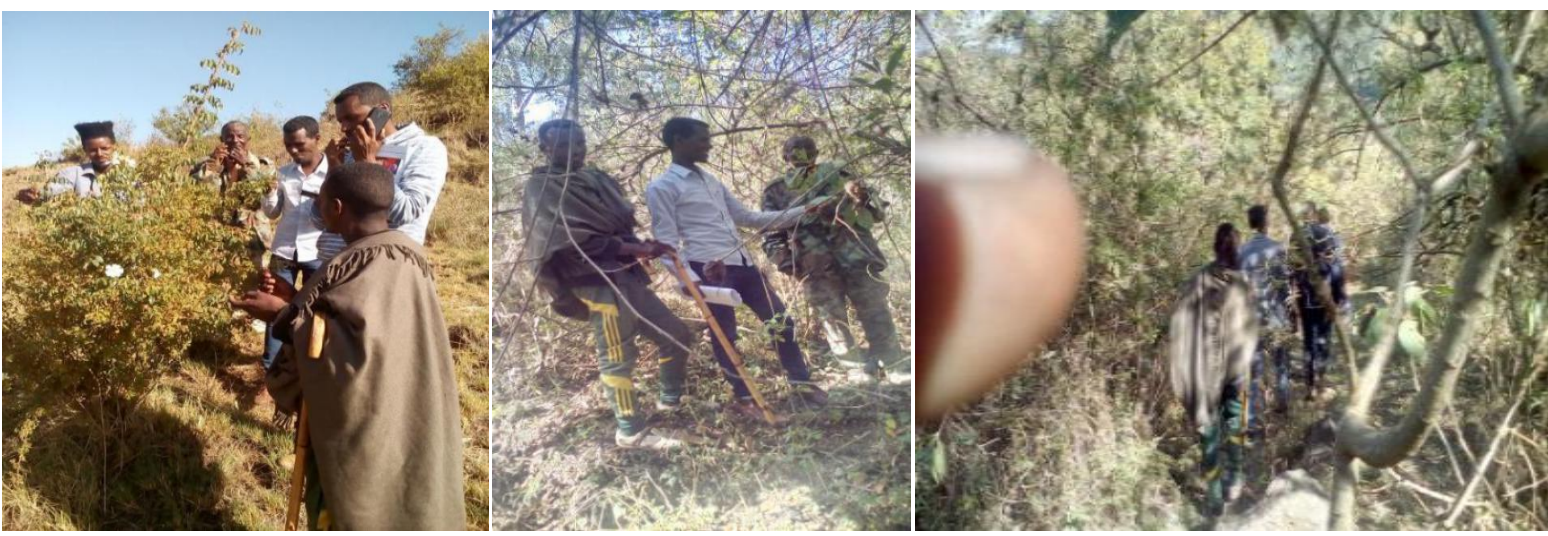

Figure 3. Guide field work with informants.

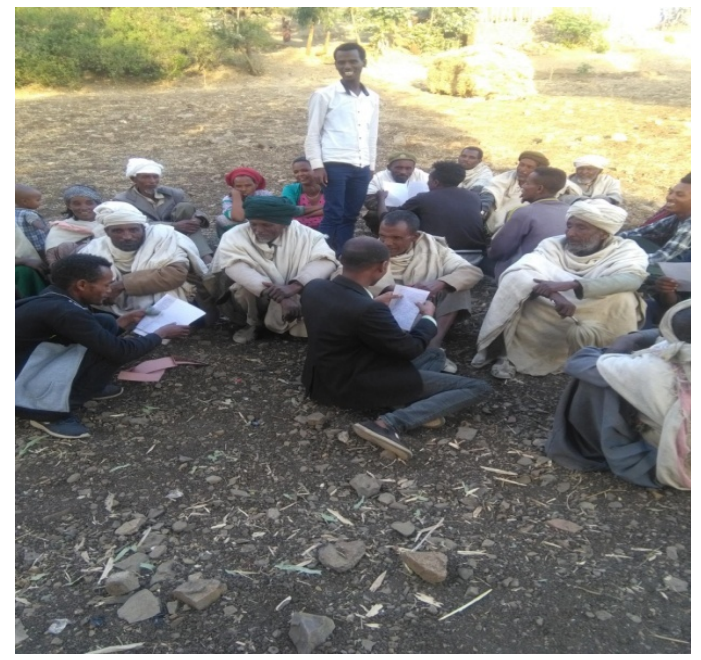

Figure 4. Focus group discussion with key informants. 
products are sold. These markets are rich sources of ethnobotanical information. The accessibility of markets, the large numbers of people involved and the public nature of the market space itself offer favorable condition for field work [12]. Weekly market survey was conducted in the study area.

\section{7) Voucher Specimen Collection and Identification}

Collection of voucher specimens was made with the help of informants and local field assistants. At this time the field activities including notes about plants and the associated indigenous knowledge were recorded. Photographic records were also taken in the field to capture the field sites, plant parts and other useful information. Preliminary identification of specimens was performed in the field to family level and some cases to species level. Further identification was made using the flora of Ethiopia and Eritrea [13].

\section{8) Data Collection of WEPs for Determination of Dietary Values}

For dietary value analysis 18 key informants were selected to establish the preference of wild edible plants for comparison [11]. The key informants include elders, WEP collectors, sellers, buyers, and widely consumers. Here focus group discussion (FGD) was administered before the key informants were subjected to comparison activities. FGD participants were requested to list down most preferred, most consumed and drought tolerant species of wild plants used by the community. A free list technique was employed to elicit information about the cultural domain of wild edible plant species from informants [14]. After they freely list the species, the participants were motivated to list again the most liked wild edible plants from the list. The overall community acceptance as food of the plant part, preference and consumption by household members irrespective of age, gender, and economic background were used as criteria for picking the target edible during focus group discussion.

The preference of selection of wild edible plants was based on combination of different criteria. The criteria included a) higher informant consensus value of the edible plants by FGD participants, b) edibility of the plant for extended period of the year, c) better harvesting value and ease of collection, d) wider distribution across different agro-ecological zones, e) use during normal times, food scarcity and famine periods, f) fast regeneration under trace moisture and short life cycle, g) availability of edible plants during collection time, and h) safety of the edible plants as confirmed by informants as used by [15].

\section{9) Ethical Consideration}

Ethical considerations were taken from the beginning to the end of data collection. All the action was based on the cultural view of the local communities in the study area. Approaching of the informants was very systematic and it was based on the rules and norms of the local community by telling the fact and convincing each informant following his or her culture strictly. They were also informed that the objective of the research is not for commercial purposes and it is only for academic reasons. This was done by showing official letter from Bahir Dar University. All informants were voluntary and gave written permission. 


\subsubsection{Methods of Data Analysis}

\section{1) Descriptive Statistical Methods}

Descriptive data analysis method was employed to summarize some of the ethnobotanical data obtained from the interviews on reported WEPs and associated knowledge. Data was entered in an excel spreadsheet and analyzed using descriptive statistics to identify the number and percentage of wild edible plant species, genera and families of WEPs, their growth forms and percentage of commonly utilized plant parts. The illustrative tables and graphs were used to summarize the data in precise form using Microsoft excel and Statistical Package for Social Sciences [16].

2) Quantitative Analytical Methods

\section{a) Preference Ranking}

Preference ranking was made following [11]. According to this scholar, doing preference ranking involves asking each selected informants to arrange some items, usually five to seven, in accordance to their perceived degree of importance in their community. In this study, six key informants were involved to rank wild edible plants according to their taste they perceived. Thus, seven wild edible plant species were listed (Mimusops kummel, Opuntia ficus-indica, Rhus gultinosa, Rosa abyssincia, Syzygium guineense, Embelia schimperi and Ficus sycomorus ranked by six key informants based on their personal preference or perception. Each rank was stated by integer values 1, 2, 3, 4, 5, 6 and 7 . The most effective plant is stated by the highest value 7 while the least important is stated by a value of one. An overall rank for the species was given by adding up these values for five key informants.

\section{b) Informant Consensus}

The relative popularity of wild edible plant species was evaluated based on the proportion of informants who independently report its food supplements (informant consensus). Selecting WEPs by using informant consensus was used to evaluate the reliability of the data. Some WEPs were well known in the study area more than others. As a result, local informants cited the most commonly used plants repeatedly as supplementary foods to the staple food [17].

\section{c) Direct Matrix Ranking}

Direct matrix ranking exercise was done for WEPs according to the information gathered from informants on the multipurpose use categories of the plants. This is done in order to compare multipurpose use of a given species and to infer the multiple values of the species as compared to other species, as recommended by [11]. Accordingly, multipurpose species were selected out of the total wild edible plants and use categories (medicinal, fodder, food, firewood, construction, charcoal, fencing and furniture) was listed for selected key informants to assign use values to each species. Each key informants were oriented to assign use values $(5=$ best, $4=$ very good, $3=\operatorname{good}, 2=$ less used, $1=$ least used and $0=$ not used). Finally, the average use-value for each category was calculated and then the mean values of each use-category was summed up for each plant species and ranked them accordingly. 


\section{Results and Discussion}

\subsection{Emic Categorization of Landscapes, Vegetation and Soil Classification}

People of the study area classify landscapes based on elevation and suitability of the land for agriculture and grazing. Accordingly, they classify landscapes into four categories. Namely, “wotageba” (land with ups and downs or undulating), "terrarama" (mountainous), "medama" (plain), and "shelequama" (valley) respectively. The indigenous people of the district classify the vegetation as "kutquato" (herbs), "chaka" (forest) and "tikil den" (plantation), respectively. People of the district have a system of grouping soils (geology) on the basis of the color, substrate and moisture content as "Kei" (red), "Tikur" (black) and "Walka” (water logged but getting cracked in dry season) soil types respectively.

Besides this, the people have their own knowledge of ecological classification based on climatic conditions; as "Kolla" (high temperature), "Woina Dega" (medium-temperature), "Dega" (low-temperature) and "Wurch" (very low temperature) areas, respectively. People in the study area having indigenous knowledge on wild edible plants based on their taste of quality such as "Merrara" (bitter taste), "Tafache" (sweet taste) and "Homettata" (sour taste) tastes respectively.

\subsection{Taxonomic Diversity of Wild Edible Plants in the Study Area}

From total of 33 WEPs encountered in the study area (Table 2), 24 (72.7\%) were woody and $9(27.3 \%)$ were herbaceous composed of 24 families. The dominant families were Moraceae, Fabaceae and Solanaceae represented by 3 species (11.5\%) of each followed by Polygonaceae and Acanthaceae that accounts 2 species $(7.7 \%)$ each (Table 3$)$.

\subsection{Growth Forms of Wild Edible Plants}

The current finding revealed that the growth habits of wild edible plants of the study area comprised trees 11 (33.3\%), shrubs 13 (39.4\%) and herbs 9 (27.3\%). The growth forms dominate by shrubs.

\subsection{Plant Parts Used}

The current study revealed that plant parts used as a food includes fruits, tubers, young stem, flower nectar, whole parts, gum, leaves and seeds. The dominant edible plant part was fruit 18 (54.5\%) followed by gum 4 (12.12\%) (Figure 5).

\subsection{Modes of Consumption}

In the study area about wild edible plants are consumed in the form of raw and cooked. Prcentage distribution on mode of consumption of wild edible plants is shown below (Figure 6).

Syzygium guineense is wild edible plant that consumed in the community in the form of fresh. The fruit of Syzygium guineense is eaten by both age groups 
Table 2. List of wild edible plants, habit, parts used and mode of consumption in Sedie Muja District.

\begin{tabular}{|c|c|c|c|c|c|c|}
\hline & Scientfic name & Family & $\begin{array}{l}\text { Localname } \\
\text { (Amharic) }\end{array}$ & $\mathrm{Ha}$. & $\mathrm{Pu}$ & Mode of consumption \\
\hline 1 & Acacia abyssinica Hochst. Ex Benth. & Fabaceae & Bazra girar & $\mathrm{T}$ & G & Chewed the gum \\
\hline 2 & Acacia seyal Del. & Fabaceae & Nech girar & $\mathrm{T}$ & G & Chewed the gum \\
\hline 3 & Acanthus polystachius Delile & Acanthaceae & Kusheslia & $\mathrm{S}$ & $\mathrm{Fl}$ & $\begin{array}{l}\text { The nectars from flowers sucked by } \\
\text { children lip }\end{array}$ \\
\hline 4 & Acanthus sennii Chiov. & Acanthaceae & Kusheslia & S & $\mathrm{Fl}$ & $\begin{array}{l}\text { The nectars from flowers sucked by } \\
\text { children lip }\end{array}$ \\
\hline 5 & Albizia schimperiana Oliv. & Fabaceae & Sessa & $\mathrm{T}$ & G & Chewed the gum \\
\hline 6 & Carissa spinarum $\mathrm{L}$. & Apocynaceae & Agam & S & $\mathrm{F}$ & Raw ripen fruit eaten \\
\hline 7 & Combretum collinum Fresen & Combretaceae & $\begin{array}{l}\text { Yekola } \\
\text { avalo }\end{array}$ & $\mathrm{T}$ & G & Chewed the gum \\
\hline 8 & Commelina benghalensis $\mathrm{L}$. & Commenliaceae & Yebre kolte & $\mathrm{H}$ & $\mathrm{T}$ & Raw tuber eaten \\
\hline 9 & Cordia africana Lam. & Boraginaceae & Wanza & $\mathrm{T}$ & $\mathrm{F}$ & Raw ripen fruit eaten \\
\hline 10 & Datura stramonium L. & Solanaceae & Astenagre & $\mathrm{H}$ & $\mathrm{Fl}$ & $\begin{array}{l}\text { The nectars from flowers sucked by } \\
\text { children lip }\end{array}$ \\
\hline 11 & Dovyalis abyssinica (A. Rich.) Warb. & Flacourtiaceae & Koshim & S & $\mathrm{F}$ & Raw ripen fruit eaten \\
\hline 12 & Embelia schimperi Vatke & Myricaceae & Enkoko & $S$ & $\mathrm{~F}$ & Raw ripen fruit eaten \\
\hline 13 & Euclea racemosa Murr. & Ebenaceae & Dedeho & S & $\mathrm{F}$ & Raw ripen fruit eaten \\
\hline 14 & Ferula communis $\mathrm{L}$. & Apiaceae & $\operatorname{Dog}$ & $\mathrm{H}$ & St & Young stem burnt with fire then eaten \\
\hline 15 & Ficus sur Forssk & Moraceae & Shola & $\mathrm{T}$ & $\mathrm{F}$ & Raw ripen fruit eaten \\
\hline 16 & Ficus sycomorus $\mathrm{L}$. & Moraceae & $B m b a$ & $\mathrm{~T}$ & $\mathrm{~F}$ & Raw ripen fruit eaten and dried fruit eaten \\
\hline 17 & Ficus vasta Forssk & Moraceae & Warka & $\mathrm{T}$ & $\mathrm{F}$ & Raw ripen fruit eaten and dried fruit eaten \\
\hline 18 & Grewia ferruginea Hochst. ex A.Rich. & Tiliaceae & Lenqata & S & $\mathrm{F}$ & Raw ripen fruit eaten \\
\hline 19 & Mimusops kummel A. DC. & Sapotaceae & Eshe & $\mathrm{T}$ & $\mathrm{F}$ & Raw ripen fruit eaten and dried fruit eaten \\
\hline 20 & Opuntia ficus-indica (L.) Miller & Cactaceae & Qulkal & $\mathrm{S}$ & $\mathrm{F}$ & Raw ripen fruit eaten \\
\hline 21 & Oxalis obliquifolia A. Rich. & Oxalidaceae & Lamcho & $\mathrm{H}$ & $\mathrm{W}$ & $\begin{array}{l}\text { Leaves burnt with fire eaten and raw leaves } \\
\text { also eaten }\end{array}$ \\
\hline 22 & Phoenix reclinata Jacq. & Arecaceae & Zembaba & $S$ & $\mathrm{~F}$ & Raw ripen fruit eaten \\
\hline 23 & Physalis peruviana $\mathrm{L}$. & Solanaceae & Awat & $\mathrm{H}$ & $\mathrm{F}$ & Raw ripen fruit eaten \\
\hline 24 & Rhus glutinosa A.Rich. & Anacardiaceae & Imbis & & & Raw ripen fruit \\
\hline 25 & Rhus vulgaris Meikle & Anacardiaceae & Qamo & S & $\mathrm{F}$ & Raw ripen fruit eaten \\
\hline 26 & Rosa abyssinica Lindley. & Rosaceae & Kega & $S$ & $\mathrm{~F}$ & $\begin{array}{l}\text { Raw ripen fruit eaten } \\
\text { and sun dried fruit eaten }\end{array}$ \\
\hline 27 & Rumex abyssinicus Jacq. & Polygonaceae & Mekemko & $\mathrm{H}$ & St & Suck liquid in the young stem \\
\hline 28 & Rumex nervosus Vahl & Polygonaceae & Embacho & $\mathrm{S}$ & St & Suck liquid in young stem and burnt with fire \\
\hline 29 & Solanum nigrum $\mathrm{L}$. & Solanaceae & Keye awat & $\mathrm{H}$ & $\mathrm{F}$ & Raw ripen fruit eaten \\
\hline
\end{tabular}




\section{Continued}

\begin{tabular}{lllllll}
\hline 30 & Sporobolus pyramidalis P.Beauv. & Poaceae & Mure & H & Se & $\begin{array}{l}\text { The seed grind into powder and baking } \\
\text { like enjera }\end{array}$ \\
31 & Syzygium guineense (Wild.) DC. & Myrtaceae & Dokma & T & F & Raw ripen fruit eaten \\
32 & Urtica simensis Steudel & Urticaceae & Sama & H & L & Leaves cooked as vegetables \\
33 & Ximenia Americana L. & Olacaceae & Enkaye & S & F & Ripen fruit eaten \\
\hline
\end{tabular}

H: herb; S: shrub, T: tree; Pu: plant parts used (St: Stem; L: Leaf; F: Fruit; Fl: Flower; Se: Seed; G: Gum; W: Whole parts; T: Tuber).

Table 3. Families distribution of wild edible plants in Sedie Muja District.

\begin{tabular}{|c|c|c|c|}
\hline & Families & Number of species & Percentage \\
\hline 1 & Moraceae & 3 & 11.54 \\
\hline 2 & Acanthaceae & 2 & 7.69 \\
\hline 3 & Anacardaceae & 2 & 7.69 \\
\hline 4 & Combretaceae & 1 & 3.85 \\
\hline 5 & Fabaceae & 3 & 11.54 \\
\hline 6 & Apocynaceae & 1 & 3.85 \\
\hline 7 & Amaranthaceae & 1 & 3.85 \\
\hline 8 & Boraginaceae & 1 & 3.85 \\
\hline 9 & Flacourtiaceae & 1 & 3.85 \\
\hline 10 & Ebenaceae & 1 & 3.85 \\
\hline 11 & Myricaceae & 1 & 3.85 \\
\hline 12 & Tiliaceae & 1 & 3.85 \\
\hline 13 & Apiaceae & 1 & 3.85 \\
\hline 14 & Arecaceae & 1 & 3.85 \\
\hline 15 & Cactaceae & 1 & 3.85 \\
\hline 16 & Rosaceae & 1 & 3.85 \\
\hline 17 & Polygonaceae & 2 & 7.69 \\
\hline 18 & Poaceae & 1 & 3.85 \\
\hline 19 & Myrtaceae & 1 & 3.85 \\
\hline 20 & Solanaceae & 3 & 11.54 \\
\hline 21 & Oxalidaceae & 1 & 3.85 \\
\hline 22 & Commenliaceae & 1 & 3.85 \\
\hline 23 & Olacaceae & 1 & 3.85 \\
\hline 24 & Urticaceae & 1 & 3.85 \\
\hline
\end{tabular}

that collected from the plant (Figure 7).

\subsection{Collection Site of Wild Edible Plants in the Study Area}

WEPs in the study areas were collected from diferent habitats (riverine areas, grazing land, road side, natural forests and grazing area. About $82.35 \%$ of WEPs 
were collected from natural forest (Figure 8).

\subsection{Seasonal Availability of Wild Edible Plants in the Study Area}

In this study, wild edible plants were available in different seasons. The highest

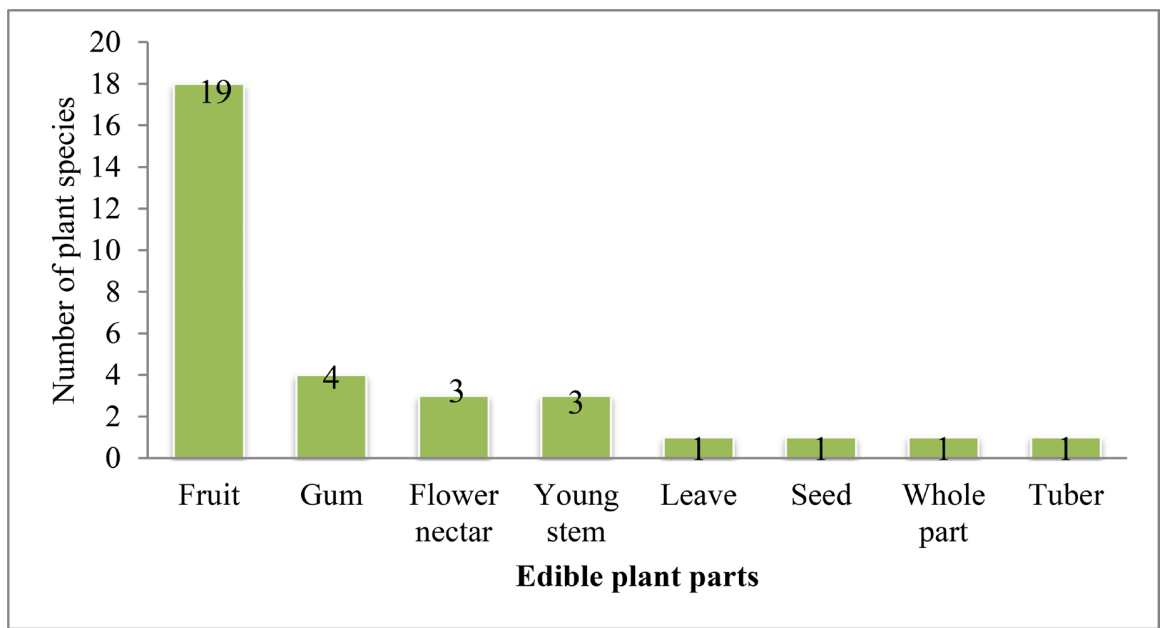

Figure 5. Frequency distribution of wild edible plant parts.

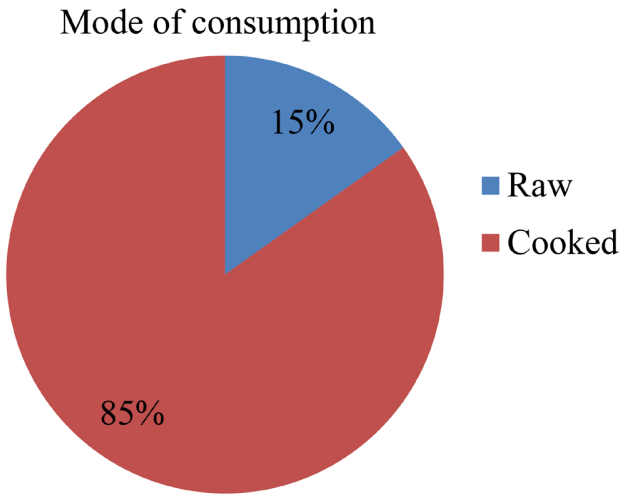

Figure 6. Percentage distribution of wild edible plants on mode of consumption.

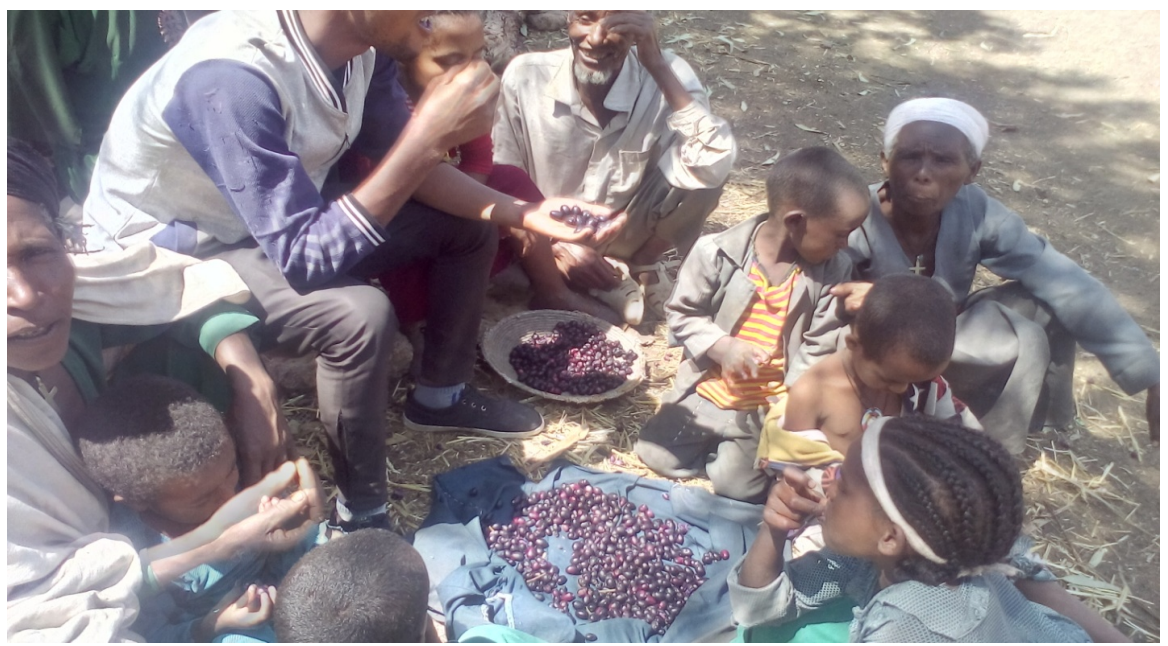

Figure 7. Fresh fruit of Syzygium guineense eaten by the people in the study area. 
number of wild edible plants were available in Ethiopian winter (June, July, August and September) 13 (39.39\%) followed by spring (March, April and May) 8 (24.24\%) (Table 4).

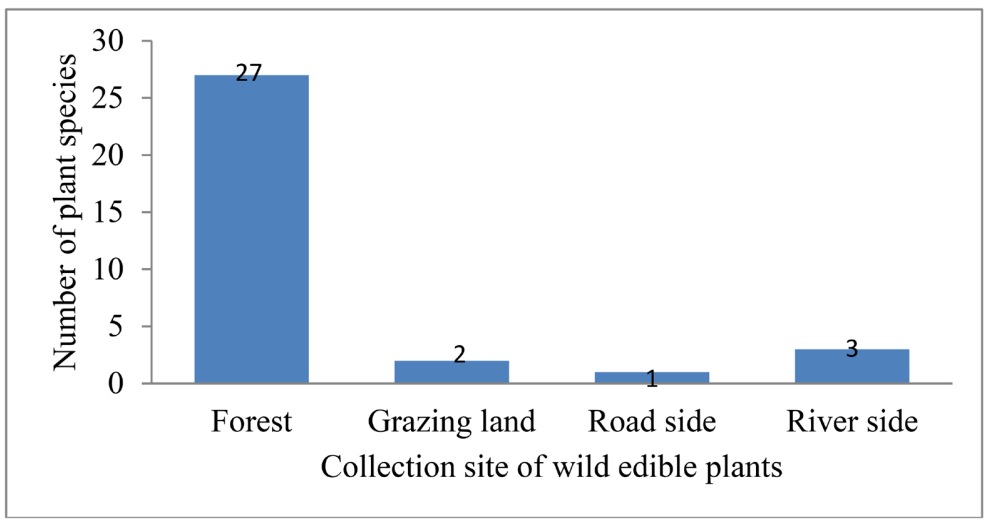

Figure 8. Collection site of wild edible plants in the study area.

Table 4. Seasonal availability of wild edible plants in Sedie Muja Distrct.

\begin{tabular}{|c|c|c|c|c|c|}
\hline Scientific name & Family & Autumn & Spring & Summer & Winter \\
\hline Acacia abyssinica Hochst & Fabaceae & 0 & 0 & 0 & + \\
\hline Acacia seyal Del & Fabaceae & 0 & 0 & 0 & + \\
\hline Acanthus polystachius Delile & Acanthaceae & + & 0 & 0 & 0 \\
\hline Albizia schimperiana Oliv. & Fabaceae & 0 & 0 & 0 & + \\
\hline Carissa spinarum $\mathrm{L}$. & Apocynaceae & 0 & + & 0 & 0 \\
\hline Combretum collinum Fresen & Combretaceae & 0 & 0 & 0 & + \\
\hline Commelina benghalensis $\mathrm{L}$. & Commelinaceae & 0 & 0 & + & 0 \\
\hline Cordia africana Lam. & Boraginaceae & 0 & 0 & 0 & + \\
\hline Datura stramonium $\mathrm{L}$ & Solanaceae & 0 & 0 & + & 0 \\
\hline Dovyalis abyssinica (A. Rich.) Warb. & Flacourtiaceae & 0 & + & 0 & 0 \\
\hline Embelia schimperi Vatke & Myricaceae & 0 & 0 & 0 & + \\
\hline Euclea racemosa Murr. & Ebenaceae & 0 & 0 & 0 & + \\
\hline Ferula communis $\mathrm{L}$. & Apiaceae & 0 & 0 & + & 0 \\
\hline Ficus sur Forssk & Moraceae & 0 & + & 0 & 0 \\
\hline Ficus sycomorus $\mathrm{L}$. & Moraceae & 0 & 0 & 0 & + \\
\hline Ficus vasta Forssk & Moraceae & 0 & 0 & 0 & + \\
\hline Grewia ferruginea Hochst ex A.Rich & Tiliaceae & 0 & 0 & + & 0 \\
\hline Mimusops kummel A. DC. & Sapotaceae & + & 0 & 0 & 0 \\
\hline Opuntia ficus-indica (L.) Miller & Cactaceae & + & 0 & + & 0 \\
\hline Oxalis obliquifolia A. Rich. & Oxalidaceae & 0 & 0 & + & 0 \\
\hline Phoenix reclinata Jacq. & Arecaceae & 0 & 0 & 0 & + \\
\hline
\end{tabular}


Continued

Physalis peruviana L.

Rhus glutinosa A. Rich.

Rhus vulgaris

Rosa abyssinica Lindley.

Rumex abyssinicus Jacq

Rumex nervosus

Solanum nigrum $\mathrm{L}$.

Sporobolus pyramidalis P. Beauv.

Syzygiumguineense (Wild.) DC.

Ximenia americana L.

Urtica simensis Steudel

$\begin{array}{ccccc}\text { Solanaceae } & 0 & + & 0 & 0 \\ \text { Anacardiaceae } & 0 & 0 & + & 0 \\ \text { Anacardiaceae } & 0 & 0 & 0 & + \\ \text { Rosaceae } & 0 & 0 & 0 & + \\ \text { Polygonaceae } & 0 & 0 & + & 0 \\ \text { Polygonaceae } & + & + & 0 & + \\ \text { Solanaceae } & + & 0 & 0 & \\ \text { Poaceae } & + & 0 & 0 & 0 \\ \text { Myrtaceae } & 0 & + & 0 & 0 \\ \text { Olacaceae } & 0 & + & 0 & 0 \\ \text { Urticaceae } & + & + & 0 & 0\end{array}$

$+=$ Available, 0 = not available, autumn $=$ September, October and November, Spring = March, April and May, Summer = June, July and August, Winter = December, January and February.

Table 5. Drying duration for some wild edible plants as reported by informants.

\begin{tabular}{cccc}
\hline Plant type & Mode of dried & Parts dried & Duration of drying \\
\hline Ficus vasta & Sun & Fruits & 1 day \\
Cordia africana & Sun & Fruits & 2 day \\
Mimusops kummel & Wind & Fruits & 3 day \\
Rosa abyssinica & Sun & Fruits & 5 day \\
\hline
\end{tabular}

Wild edible plants are dried for further use, the plant species Ficus vasta, Cordia africana and Rosa abyssinica fruits are dried by the sun while Mimusops kummel was dried by wind. Duration of drying was shown in (Table 5).

\subsection{Shelf Life of Wild Edible Plants after Drying Reported by Informants}

In this study, four wild edible plants have different shelf life after drying by the sun. Rosa abyssinica has the highest shelf-life followed by Cordia africana and the least shelf life was reported in Mimusops kummel(2) (Figure 9).

\subsection{Harvesting Techniques of Wild Edible Plants Reported by Informants}

Wild edible plants were mainly harvested using three rudimentary methods, namely digging (tubers and roots), plucking from plants (fruits, stem, seeds, and gum), and ground collection of fallen seeds and fruits. The prominent of these techniques were plucking from mother plants (27), the lowest harvesting technique was performed by digging (2) (Figure 10).

\subsection{Marketability of Wild Edible Plants in the Study Area}

The wild edible plants in the study area are almost not sold in the local market 
except few plants as food. The sellable ones were Syzygium guineense and Mimusops kummel (Figure 11).

\subsection{Quantitative Data Analyses on Wild Edible Plants in Sedie Muja District}

\subsubsection{Informant Consensus}

Some wild edible plants were well known in the study area more than others. As

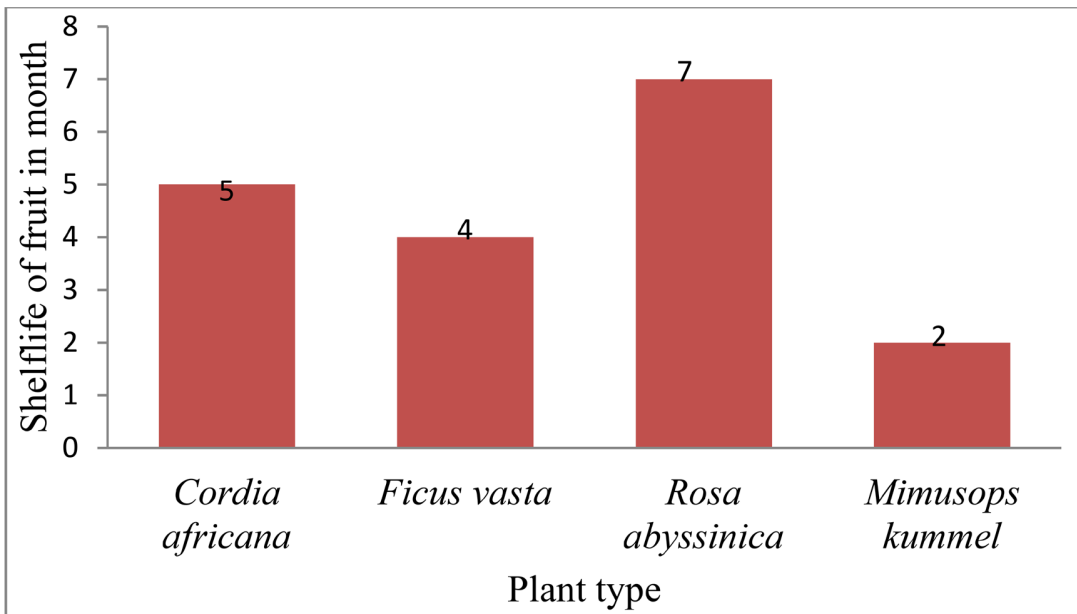

Figure 9. Shelf life of wild edible plant fruits (after drying) in the study area.

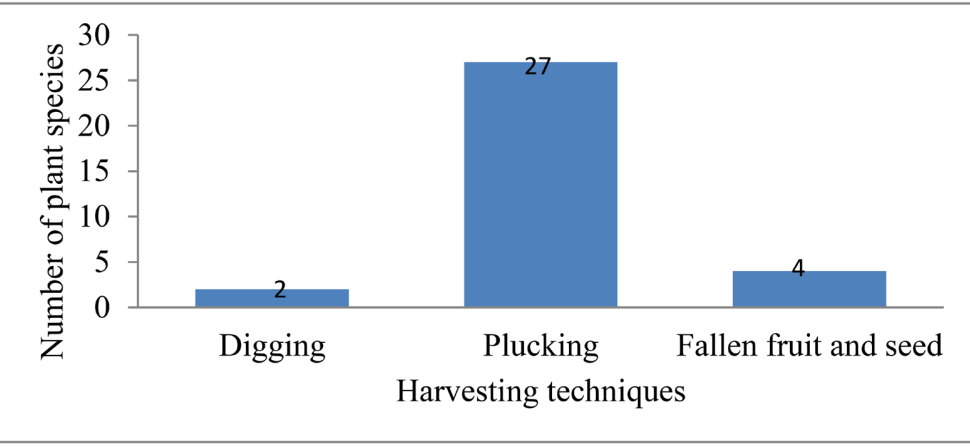

Figure 10. Harvesting techniques of wild edible plants in the study area.
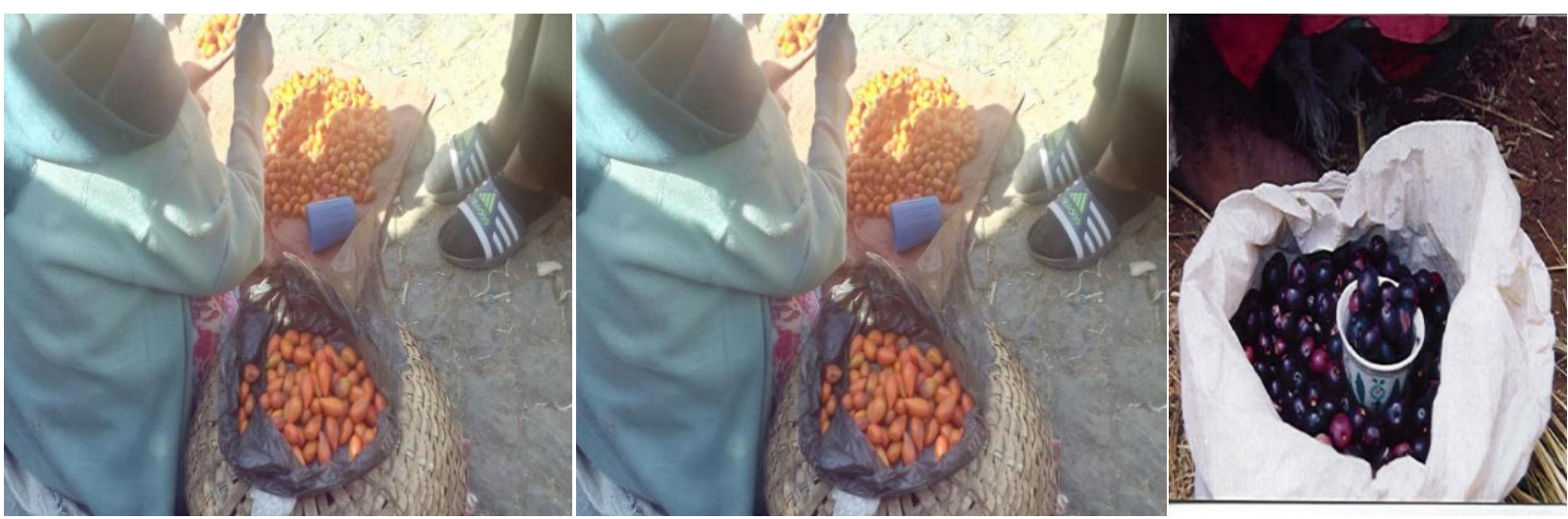

Figure 11. Some wild edible plants sold at local market in the study area. 
a result, local informants cited the most commonly used plants repeatedly as supplementary foods to the staple food. For example, Rossa abysinica was the most popular, cited by $75(89.2 \%)$ informants for its food value, followed by Rhus glutinosa cited by 61 (72.6\%) informants (Table 6).

\subsubsection{Preference Ranking}

Preference of edibility for seven wild edible plants based on taste of quality perceived by informants in Sedie Muja District (Table 7) showed that Opuntia ficus-indica ranked first followed by Syzygium guineense.

\subsubsection{Direct Matrix Ranking}

Direct matrix ranking was performed to assess the relative importance each plant. The result of the direct matrix ranking showed that Ficus sur stood first in being the most multipurpose wild edible plant and Ficus sycomorus was the least. From the use categories firewood was the leading and forage was the least (Table 8).

Table 6. Informant consensus on the most frequently used wild edible plant in the study area.

\begin{tabular}{ccc}
\hline Scientific Name of Wild Edible Plants & No. of Informants & Percentage \\
\hline Rosa abyssinica & 75 & 89.2 \\
Rhus glutinosa & 61 & 72.6 \\
Rumex nervosus & 58 & 69 \\
Ficus sycomorus & 45 & 54.7 \\
Oxalis obliquifolia & 41 & 48.8 \\
Ferula communis & 38 & 45.2 \\
Cordia africana & 31 & 36.9 \\
Mimusops kummel & 25 & 29.7 \\
Syzygium guineense & 21 & 25 \\
\hline
\end{tabular}

Table 7. Preference ranking of seven wild edible plants based on their taste.

\begin{tabular}{ccccccccc}
\hline \multirow{7}{*}{ Plant types } & \multicolumn{7}{c}{ Key informants } \\
\cline { 2 - 10 } & R1 & R2 & R3 & R4 & R5 & R6 & Score & Rank \\
\hline Mimusops kummel & 2 & 6 & 4 & 1 & 3 & 2 & 18 & $5^{\text {th }}$ \\
Opuntia ficus-indica & 4 & 3 & 7 & 5 & 3 & 4 & 26 & $1^{\text {st }}$ \\
Rhus gultinosa & 2 & 2 & 6 & 3 & 2 & 1 & 16 & $6^{\text {th }}$ \\
Rosa abyssinica & 5 & 3 & 2 & 6 & 3 & 1 & 21 & $4^{\text {th }}$ \\
Syzygium guineense & 5 & 4 & 4 & 3 & 2 & 6 & 24 & $2^{\text {nd }}$ \\
Embelia schimperi & 1 & 2 & 2 & 5 & 3 & 1 & 14 & $7^{\text {th }}$ \\
Ficus sycomorus & 3 & 2 & 2 & 7 & 4 & 4 & 23 & $3^{\text {rd }}$ \\
\hline
\end{tabular}




\subsubsection{Variation of Indigenous Knowledge on Use of Wild Edible Plants in Different Informant Groups}

Indigenous knowledgeable were higher in males. They knew more about wild edible plants than females. More knowledge of wild edible plants in the study area was obtained from elder informants, when compared with the young people. The same is true there was a significant difference $(\mathrm{P}<0.05)$ in the number of wild edible plants reported by different informant groups such as age, literacy and marital status. In age group informants having age $>35$ listed more wild edible plants than young ages (15 - 35). Based on literacy level illiterate informants knew more wild edible plants than literate one and indigenous knowledge was much in married informants than single informants (Table 9).

\section{Discussion}

Indigenous people living in the study area had their own classification system of landscape, vegetation and soil based on their associated knowledge. To classify

Table 8. Direct matrix ranking on six wild edible plant species.

\begin{tabular}{ccccccccc}
\hline Use categories & $\begin{array}{c}\text { Ficus } \\
\text { sur }\end{array}$ & $\begin{array}{c}\text { Acanthus } \\
\text { senii }\end{array}$ & $\begin{array}{c}\text { Acacia } \\
\text { abyssinica }\end{array}$ & $\begin{array}{c}\text { Rhus } \\
\text { glutinosa }\end{array}$ & $\begin{array}{c}\text { Ficus } \\
\text { sycomorus }\end{array}$ & $\begin{array}{c}\text { Ficus } \\
\text { Vasta }\end{array}$ & Total & Rank \\
\hline Fire wood & 2 & 5 & 3 & 3 & 1 & 5 & 20 & $1^{\text {st }}$ \\
Charcoal & 5 & 0 & 4 & 4 & 2 & 4 & 17 & $4^{\text {th }}$ \\
Medicine & 2 & 3 & 4 & 3 & 2 & 1 & 14 & $5^{\text {th }}$ \\
Building & 5 & 1 & 1 & 2 & 1 & 3 & 21 & $2^{\text {nd }}$ \\
Forage & 1 & 2 & 2 & 2 & 1 & 1 & 10 & $6^{\text {th }}$ \\
Furniture & 5 & 2 & 4 & 1 & 3 & 3 & 19 & $3^{\text {rd }}$ \\
Total & $\mathbf{2 0}$ & $\mathbf{1 3}$ & $\mathbf{1 8}$ & $\mathbf{1 5}$ & 10 & 17 & 12 & \\
Rank & $\mathbf{1}^{\text {st }}$ & $5^{\text {th }}$ & $2^{\text {nd }}$ & $4^{\text {th }}$ & $6^{\text {th }}$ & $3^{\text {rd }}$ & & \\
\hline
\end{tabular}

Table 9. Knowledge variation of Sedie Muja district community on wild edible plants.

\begin{tabular}{lllcccc}
\hline \multicolumn{1}{c}{ Parameter } & \multicolumn{1}{c}{$\begin{array}{c}\text { Informant } \\
\text { groups }\end{array}$} & $\mathbf{N}$ & $\begin{array}{c}\text { No. of plant } \\
\text { species reported }\end{array}$ & Mean \pm SD & t-value & P value \\
\hline Gender & Female & 34 & 101 & $2.96 \pm 1.26$ & 5.6 & 0.00 \\
& Male & 50 & 234 & $4.68 \pm 1.35$ & & \\
Age & $15-35$ & 35 & 95 & $2.7 \pm 1.40$ & & 0.00 \\
& $>35$ & 50 & 289 & $5.9 \pm 2.24$ & & \\
Literacy & Literate & 30 & 90 & $3 \pm 1.20$ & & 0.002 \\
& Illiterate & 54 & 215 & $3.98 \pm 1.46$ & & \\
Marital status & Single & 33 & 218 & $6.4 \pm 2.45$ & & -2.94 \\
& Married & 51 & 375 & $7.5 \pm 2.10$ & & 0.004 \\
\hline
\end{tabular}

Significant difference $(\mathrm{P}<0.05), \mathrm{t}(0.05), \mathrm{df}=82, \mathrm{~N}=$ number of respondents. 
these natural resources they used their own indigenous knowledge. IK methods, which they use to classify landscape is based on the nature of the topography, for example high peak area they called mountainous, if at the tip of the mountain is flat area they called it "Amba". Similarly, IK systems, which they use to classify vegetation, are based on size, shape and length.

Soil was also classified based on colour, texture and suitability for crop cultivation. For example, "Keyatie" is for red soil with low fertility with finely course texture and poor for crop cultivation. This soil used traditionally to prepare house material. "Walka" is soil type that have colour of black. The local people have a system identifying the most fertile soil. This is also indicated in similar studies elsewhere in Ethiopia [18] [19].

\subsection{Diversity of Wild Edible Plants in Sedie Muja Area}

Sedie Muja District has low diversity of wild edible plants as compared to others part of Ethiopia. That were [20] reported 137 wild edible species used by the Konso ethnic community in Southern Ethiopia and [9] documented 66 wild edible plant species in Derashe and Kucha Districts in Southern Ethiopia. Wild Edible Plants diversity in Sedie Muja District was similar to that of Chilga district in Semen Gondar Zone in which, [8] reported that were 33 Wild and semi-wild edible plants in Chilga District, Northwestern, Ethiopia.

The study area also has comparable WEP diversity with Kemashi district in Benshangul Gumuz region [1] documented 35 species but higher diversity than that of Bule Hora district Southern Ethiopia Region [21] which were 29 species. The possible explanation for these differences could be the differences in local traditions and customs of using these plants and the climatic and environmental conditions that might have restricted the number of wild edible plants from region to region. Fabaceae, Moraceae and Solanaceae had the highest proportion of wild edible species represented by three species in each family. This result was in contrast with [22] in Chelia District, West-Central Ethiopia where family Moraceae had more WEP 5 (16.66\%) followed by Asteraceae. The numbers of families in the present study were higher than study conducted by [21] in Bule Hora district Southern Ethiopia was 22 families.

Trees, shrubs and herbs were found to be the sources of wild food plant species in this study. The dominant growth was formed by shrubs 13 (39.04\%). In this finding the growth form was dominated by shrubs similar to what was found by [23] in Burji District, Segan Area Southern Nations, Nationalities and People Region (SNNPR), Ethiopia and [24] in Berehet District, North Shewa Zone of Amhara Region (Ethiopia). These similarities could be due to similarities in climatic and other environmental conditions.

Fruits are the most important edible plant parts. This might be due to their taste they are, delicious and easily accessible and edible from the wild without any processing. As a result, fruits are important sources of essential vitamins and minerals for the communities in the study area. This finding agree with [24] where fruits were reported as the most utilized plant parts out of the total parts 
used in Amaro District of Southern Nations, Nationalities and Peoples Region and Gelana District of Oromia Region, Southern Ethiopia

This study revealed that most of the recorded wild edible plant species or their parts were consumed as raw without further processing. Five wild plant species (Urtica simensis, Sporobolus pyramidalis, Oxalis obliquifolia Rumex nervosus, and Ferula communis are reported to be cooked before consumption. The high percentage of raw edibles may be due to the nature of the fruits that are not needed further processing and it might be good to consume in raw forms and the other reason might be raw fruits are good source of nutrients that does not loss its nutrients but if it is boiled or cooked some essential nutrients might be lost. This is consistent with other findings including these of [9]. But, this is contrasted with the finding of [4] studied in southern Ethiopia, who indicated that sixteen (41\%) wild edible plants were used as vegetables by harvested their leaves, young twigs, upper parts (leaf and stem). [25] in the abroad who indicated also that most of the edible plant parts were leaves which were consumed after cooking.

The present study had shown that wild edible plants are integral part of the diet of local people of the study area at times of both food plenty and scarcity. The findings of this study revealed that wild edible plants were collected from a variety of habitats such as roadsides, forests, and grazing land. Similar results were reported by [23] who said that in Burji District, Segan Area Zone of Southern Nations, Nationalities and Peoples Region (SNNPR), wild edible plants were collected from various habitats including roadsides, grazing land, forests and riverside and Eastern Showa of Ethiopia wild food plants were collected by the communities from woodlands, scrublands, rocky hillsides, degraded wood and grazing and browsing areas and spiritually protected areas reported by [6].

The result of this study made known that the most common harvested growth forms of wild edible plants were shrubs and herbs. This could be due to their presence in high diversity in the district. The analysis results shown in (Table 2) showed that Sedie Muja District is rich in wild food plants. These wild food species recorded in this study were edible in normal times as well as at times of food shortage so as to prevent starvation and sustain life during prolonged drought and social unrest. The part of one species, namely Sporobolus pyramidalis reported as consumed only during sever famine when preferred alternatives are not available. The role of wild food plants mainly during unsustainable conditions was also explained by [20] [26] [27].

In the present study, the highest numbers of wild edible plants were available in the winter season 13 (39.04\%) species. Since most of the plants were drought resistant, they were found producing fruits, unlike staple food crops which failed during drought and erratic rainfall availability. The season and frequency of harvesting vary from plant to plant depending on the availability of edible plants and parts. It also varied from place to place due to ecological and climatic conditions. For example, Opuntia ficus-indica produces edible parts twice and is best collected for consumption within one month time. 
Some wild edible herbs such as Oxalis obliquifolia and Ferula communis were available only during summer season. Hence, collectors of WEPs need to know their seasonal availability. The result on seasonal availability of wild edibles in Sedie Muja was different from that of the study conducted in Chilga district by [8] where WEP was available in March and June (dry season) and study by [6] in Semiarid East Shewa, Ethiopia also reported that wild edible plants were most abundant from February to April during the short rainy season. This variation in the availability of wild edible plants could be due to climatic, environmental and altitudinal differences.

According to [3] seasonal food shortages, when household stocks were empty and the new crop was still in the field were common times to collect, sell and consuming underutilized edible plants. Poorest communities are more vulnerable to drought thus are more dependent on these plants. To overcome this problem the local communities in the study area collected and dried wild edible plants for further use in the study area, the plant species Ficus vasta, Cordia africana and Rosa abyssinica fruits were dried by the sun while Mimusops kummel was dried by wind. Duration of drying was one day (Ficus vasta) two day (Cordia africana) three day (Mimusops kummel) and five day (Rosa abyssinica). In this study, Rosa abyssinica takes more time to dry but the least was found in $\mathrm{Fi}$ cus vasta. This might be due to the nature of the seed coat and morphological strength of the fruits.

In this study, four wild edible plants reported by informants have a different shelf life after drying. The time that stayed for food were Rosa abyssinica (7), Cordia africana (5), Ficus vasta (4) and Mimusops kummel (2) months respectively. From these Rosa abyssinica has the highest shelf-life followed by Cordia Africana and Ficus vasta the least shelf life was reported in Mimusops kummel. Higher shelf life in Rosa abyssinica might be based on the compositional components of the fruit. The present study shows higher extending shelf life than a study conducted by [28] in Portugal on smoking involves exposure of fish to wood smoke, which can be done at a relatively low temperature, $30^{\circ} \mathrm{C}$, in which case the process is known as cold smoking. During smoking there may occur a loss of moisture of $10 \%-11 \%$ and the cold-smoked fish products can be refrigerated, which gives them a shelf life of about 7 days which has less shelf life than plant fruits of the present study.

The most dominant method in wild edible plant harvesting techniques was plucking from the mother plants; this might be due to ease way of collection than the other harvesting techniques. This finding agrees with study conducted by [29] on wild edible plants used by communities in and around selected forest reserves of Teso-Karamoja region, Uganda.

Very few wild food plants are sold in markets as sources of income generation. Very few wild edible plants are sold in markets. This was related to cultural challenges of the community. When they sell wild edible plants, they think that they loss their dignity and the community insults them as Awt shache (wild fruit 
seller). Moreover, most of the marketable wild edible plants are not available as they used to be. This was proved from the observation of markets and the discussion with merchants. The sources of the wild food found in the market were sold by young to medium aged groups of merchants. A few numbers of wild foods sold in the market were also reported by other studies made in Ethiopia [8] [30].

\subsection{Variation of Indigenous Plant Knowledge}

Wild edible plant knowledge among different social groups may not be the same and this is confirmed after doing different analyses. In Sedie Muja, male populations were more knowledgeable than females. This might be due to occupation difference, males highly intracting with wild edible plants during caw keeping, collection of timber for house construction. This was not true in the study by [22] in Chelia District, West-Central Ethiopia where Women were more knowledgeable than males. More knowledge of wild edible plants in the study area was obtained from elder informants, when compared with the young people. Youths tend to bend towards modernity and new cultures, which they consider to be more advanced. In age group informants having age $>35$ listed more wild edible plants than age (15 - 35), likewise, illiterate informants knew more wild edible plants than literate ones and indigenous knowledge was much in married informants than that of single informants. This result did not agree with [23] where he showed women and children usually going out into the field and forests to collect a variety of leaves, roots, seeds, and fruits.

\section{Conclusions and Recommendation}

A total of 33 wild edible plant species were recorded in Sedie Muja District. These wild edible plants are especially consumed during food scarcity and extra food in addition to the cultivated plants. The local communities have the indigenous knowledge to use these wild edible plants. Wild edible plants play an important role in the daily life of the local people considering in terms of dietary nutrition. The 3 selected wild edible plant species that are mostly used by the people of Sedie Muja District contain different nutritional compositions that are important to the diet.

Domestication of such wild edible plants should be encouraged with proper conservation measures, sustainable utilization and harvesting of the resources to preserve the local gene pool and associated indigenous knowledge. Agricultural expansion on farm lands through clearing forests should be stopped by inducing intensive agricultural activities than extensive ones through fulfilling different inputs. The local people need awareness-raising interventions about the sustainable use of natural resources.

\section{Acknowledgements}

My deepest gratitude goes to Bahir Dar University. I also extend my profound 
thanks and appreciation to District Agricultural offices, enumerators, development agents, farmers and the general respondents for their cooperation and enormous contribution to this research project.

\section{Conflicts of Interest}

The authors declare no conflicts of interest regarding the publication of this paper.

\section{References}

[1] Dessalegn, A. (2017) Ethnobotanical Survey of Wild Edible Plants and Their Contribution for Food Security Used by Gumuz People in Kamash Woreda; Benishangul Gumuz Regional State, Ethiopia. Journal of Food and Nutrition Sciences, 5, 217-224. https://doi.org/10.11648/j.jfns.20170506.12

[2] Tapan, S., Basundhara, P. and Kausik, C. (2017) Nutritional Potential of Five Unexplored Wild Edible Plants Consumed by the Tribal People of Arunachal, India. International Journal of Food Science and Nutrition, 2, 101-105.

[3] Ermias, L., Zemede, A., Ensermu, K. and Patrick, V. (2011) Wild Edible Plants in Ethiopia: A Review on Their Potential to Combat Food Insecurity. Africa Focuses, 24, 71-121. https://doi.org/10.1163/2031356X-02402006

[4] Tilahun, T. and Mirutse, G. (2010) Ethnobotanical Study of Wild Edible Plants of Kara and Kwego Semi-Pastoralist People in Lower Omo River Valley, Debub Omo Zone, SNNPR, Ethiopia. Journal of Ethnobiology and Ethnomedicine, 4, 6-23. https://doi.org/10.1186/1746-4269-6-23

[5] Santosand, F. (1975) Nutritional Value of Some Edible Leaves Used in Mozambique. Economic Botany, 29, 255-263. https://doi.org/10.1007/BF02873175

[6] Debela, H., Jesse, N. and Zemede, A. (2011) Seasonal Availability and Consumption of Wild Edible Plants in Semiarid Ethiopia: Implications to Food Security and Climate Change Adaptation. Journal of Horticulture and Forestry, 3, 138-149.

[7] Tilahun, T. (2010) Ethnobotanical Knowledge and Agro Ecology. Critical Reviews in Plant Science, 30, 198-225. https://doi.org/10.1080/07352689.2011.554492

[8] Mekuanen, T., Yohannis, G., Tadesse, M., Asmamaw, A., Amsalu, A. and Dagim, F. (2018) Uses of Wild Edible Plants in Quara District, Northwest Ethiopia: Implication for Forest Management. Agriculture and Food Secure, 7, 12-35. https://doi.org/10.1186/s40066-018-0163-7

[9] Kebu, B. and Fasil, K. (2006) Ethnobotanical Study of Wild Edible Plants in Derashe and Kucha Districts, South Ethiopia. Journal of Ethnobiology and Ethnomedicine, 2, 53-75. https://doi.org/10.1186/1746-4269-2-53

[10] Sedie Muja District Agricultural Office (MSDAO) (2017) Annual Work Report, Sedie Muja District, South Gondar Administrative Zone. Unpublished.

[11] Martin, G.J. (1995) Ethnobotany: A Method Manual. Chapman and Hall, London.

[12] Alexiades, M.N. (1996) Collecting Ethnobotanical Data: An Introduction to Basic Concepts and Techniques. In: Alexiades, M. and Miguel, N., Eds., Selected Guidelines for Ethnobotanical Research, The New York Botanical Garden, Bronx, 53-94.

[13] Hedberg, I., Friss, I. and Persson, E. (2009) Flora of Ethiopia and Eritrea. The National Herbarium, Addis Ababa and Uppsala, Vol. 8, 1-331.

[14] Silva, V.A., Andrade, L. and Albuquerque, U.P. (2006) Revising the Cultural Significance Index: The Case of the Fulnio in Northeastern Brazil. Field Methods, 18, 
98-108. https://doi.org/10.1177/1525822X05278025

[15] Getachew, A., Urga, K. and Dikasso, D. (2005) Ethnobotanical Study of Edible Wild Plants in Some Selected Districts of Ethiopia. Human Ecology, 33, 83-118.

https://doi.org/10.1007/s10745-005-1656-0

[16] SPSS Version 20 (2020) IBM SPSS Statistical Package.

[17] Leonti, M., Vibrans, H., Sticher, O. and Heinrich, M. (2001) Ethnopharmacology of the Populace, Mexico: An Evaluation. Journal of Pharmaceutical Pharmacology, 53, 1653-1669. https://doi.org/10.1211/0022357011778052

[18] Tinsae, B. (2009) An Ethnobotanical Study of Plants Used by the Local People in and around the Semi-Arid Awash National Park, Ethiopia. M.Sc., Addis Ababa University, Addis Ababa.

[19] Moa, M. (2010) Ethnobotanical Study of Medicinal Plants in Wayu Tuka Wereda, East Wollega Zone of Oromia Region, Ethiopia. M.Sc. Thesis, Addis Ababa University, Addis Ababa.

[20] Getachew, A., Zemede, A. and Zerihun, W. (2013) Ethnobotany of Wild and Semi-Wild Edible Plants of Konso Ethnic Community, South Ethiopia. Journal of Ethnobotany, 11, 121-141.

[21] Tariku, B. and Eyayu, M. (2017) Study on the Diversity and Use of Wild Edible Plants in Bullen District Northwest Ethiopia. Journal of Botany, 2017, Article ID: 8383468. https://doi.org/10.1155/2017/8383468

[22] Tena, R., Ensermu, K. and Zemede, A. (2014) Ethnobotany of Wild and Semi-Wild Edible Plants of Chelia District, West-Central Ethiopia. Science, Technology and Arts Research. Journal Science and Technology, 3, 122-134. https://doi.org/10.4314/star.v3i4.18

[23] Mersha, A., Zemede, A. and Ensermu, K. (2016) Ethnobotanical Study of Wild Edible Plants in Burji District, Segan Area Zone of Southern Nations, Nationalities and Peoples Region (SNNPR), Ethiopia. Journal of Ethnobiology and Ethnomedicine, 8, 12-32. https://doi.org/10.1186/s13002-016-0103-1

[24] Getu, A. (2017) Plant Diversity and Ethnobotany of Medicinal and Wild Edible Plants of Amaro District of Southern Nations, Nationalities and Peoples Region and Gelana District of Oromia Region, Southern Ethiopia. PhD Dissertation, Addis Ababa University, Addis Ababa.

[25] Ali-Shtayeh, M.S., Jamous, R.M., Shafie, J., Elgharabah, W., Kherfan, F., Qarariah, K., Khdair, I., Soos, I., Musleh, A., Isa, B., Herzallah, H., Khlaif, R., Aiash, S., Swaiti, G., Abuzahra, M., HajAli, M., Saif, N., Azem, H. and Nasrallah, H. (2008) Traditional Knowledge of Wild Edible Plants Used in Palestine. Journal of Ethnobiology and Ethnomedicin, 4, 13-60. https://doi.org/10.1186/1746-4269-4-13

[26] Cotton, C.M. (1996) Ethnobotany: Principles and Applications. John Wiley and Sons Ltd., Chichester.

[27] Zemede, A. and Mesfin, T. (2001) Prospects for the Sustainable Use and Development of Wild Food Plants in Ethiopia. Economic Botany, 55, 47-62.

https://doi.org/10.1007/BF02864545

[28] Raquel, P. (2018) The Drying of Foods and Its Effect on the Physical-Chemical, Sensorial and Nutritional Properties. International Journal of Food Engineering, 4, 93-100. https://doi.org/10.18178/ijfe.4.2.93-100

[29] Ojelel, S., Mucunguzi, P. and Katuura, E. (2017) Wild Edible Plants Used by Communities in and around Selected Forest Reserves of Teso-Karamoja Region, Uganda. Journal of Ethnobiology and Ethnomedicine, 15, 3-25. 
https://doi.org/10.1186/s13002-018-0278-8

[30] Zemede, A. (2009) The Future of Wild Food Plants in Southern Ethiopia: Ecosystem Conservation Coupled with Enhancement of the Roles of Key Social Groups. Symposium on Underutilized Plants for Food Security in Ethiopia, Addis Ababa, 31 January 2009, 701-708. https://doi.org/10.17660/ActaHortic.2009.806.87 